\title{
Decision Analysis of Giving Credit Using Pairwise Comparisons and Scoring Methods (Case Study: Bank XYZ)
}

\author{
Prima Priangga ${ }^{1}$, Erma Suryani ${ }^{2}$
}

\begin{abstract}
Kredit Usaha Rakyat (KUR) is a type of credit given by Bank for segment business Micro, Small and Medium Enterprises (UMKMK). Along with the high interest of the community in applying for credit to the Bank, it raises its problems, namely determining the feasibility of customers. Determining this feasibility is important, considering that KUR is one of the Government's programs in empowering the UMKMK industry sector so that the risk of non-performing loans is expected to be minimized. The method used in this study is the Pairwise Comparisons and Scoring, based on the consideration that Pairwise Comparisons and Scoring are aids in priority of criteria, the priority of sub-criteria and giving scoring to determine lending decisions. Pairwise Comparisons are the basic concepts of the Analytical Hierarchy Process, which have been proven to solve decision problems which involve many complex criteria. The results obtained in this study are the priority of criteria, the priority of, and scoring of debtors for the determination of debtors who are eligible or not eligible for receive credit - $\mathbf{3 0}$ debtors who were sampled in this study. There were 17 debtors eligible to receive credit and 13 debtors were not eligible to receive credit.
\end{abstract}

Keywords - Credit, Pairwise Comparisons, Scoring, Decision.

\section{INTRODUCTION}

$\mathrm{K}$ redit Usaha Rakyat (KUR) is credit or financing of working capital and or investment to individual debtors, business entities, or business groups that are productive and feasible, but do not have additional collateral. Micro, Small, Medium Enterprises (UMKMK) that are expected to be able to access KUR are those engaged in the productive business sector. KUR distribution can be done directly, where UMKMK can directly access KUR at the Executing Office Bank. However, to bring services closer to micro businesses, KUR distribution can also be done indirectly, meaning micro businesses can access KUR through linkage program activities in collaboration with Banks.

For accepting KUR, the prospective debtor must prepare a proposal that generally contains the business conditions, why it requires additional, organizational structure, the legality of the business and plan for the assets to be pledged. Then the proposal is sent to the Bank. After the proposal is sent to the Bank, the Bank will examine the proposal for completing administrative requirements, if it is complete it will continue to be examined in the Sistem Informasi Debitur (SID) of Bank Indonesia, if it is not included in the category of default debtors, it will continue continued evaluation process by the Bank.

These conditions turned out to be insufficient to screen potential debtors, so that problems arose, namely bad credit or customers could not pay the obligations that had been agreed. These are because the selection and analysis process for determining the prospective debtor is still considered inappropriate. For this reason, it is necessary to select prospective borrowers more measurably, so that these problems can be minimized.

In previous researches, analysis for lending decisions

${ }^{1}$ Prima Priangga is with Department of Business and Technology Management, Institut Teknologi Sepuluh Nopember, Surabaya, 60111, Indonesia. E-mail: primapriangga1983@gmail.com

${ }^{2}$ Erma Suryani is with Department of Information Technology and Communication, Institut Teknologi Sepuluh Nopember, Surabaya, 60111, Indonesia. E-mail: erma.suryani@gmail.com has been carried out with various methods and has resulted in several decision analysis that can help provide an initial assessment of whether the debtor is feasible or not eligible to receive credit $[1][2][3][4]$, and [5] However, among one study of other studies, it does not necessarily apply to different banks, considering the condition of each bank may differ according to the characteristics of each bank

In general, the analysis of lending uses 5C (Character, Capital, Capacity, Collateral, Condition Economy) analysis. Analysis of $5 \mathrm{C}$ is the main criterion in analyzing lending, which will be added to the description of sub-criteria from each of the main criteria.

This condition was carried out in previous researches [6][7], and [8] with the selection of different sub-criteria and assessment of sub-criteria so that the results obtained were different. With these differences in assessment, this study aims to complement previous researches by modifying the sub-criteria used and adding scoring weights to each selected sub-criteria.

With a sufficient number of criteria that must be met by customers, a Multi-Criteria Decision Making (MCDM) method is needed to select the submission of facilities based on credit policy criteria that have been set to obtain priority customers who will receive the facility. Multi-Criteria Decision Making (MCDM) seeks to determine the suitability of the results of several alternatives of a decision taking into account several criteria. The concept of Pairwise Comparisons (PC) is used by many MCDM methods [9][10][11][12], and [13]. PC's allow solving bigger decision problems into smaller, more structured, and easily managed sequences to facilitate separation of problems. Each PC allows decision makers to consider decision elements and determine the preferences of each element.

The primary purpose of this study is to analyze: (1) determine the priority of the main criteria for prospective debtors; (2) determine the priority of the main subcriteria for prospective debtors; (3) determine the scoring of prospective borrowers; (4) obtain the results of testing the Pairwise Comparisons and Scoring methods in the analysis of lending decisions. 


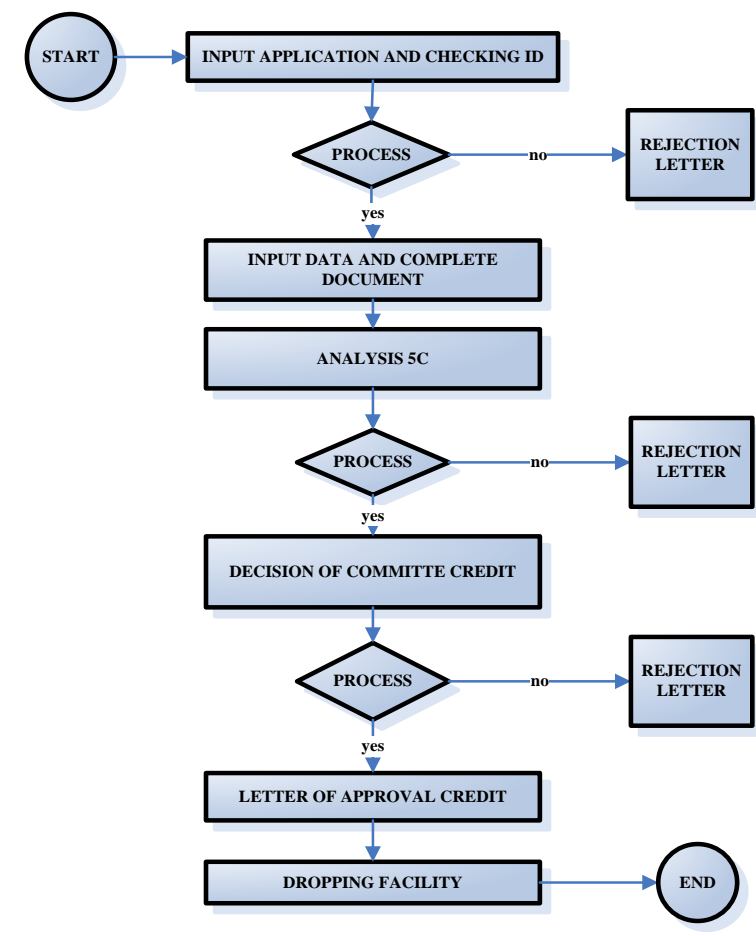

Figure 1. Flow Chart of Processing Credit.

The definition of credit, in general, is something that has an economic value at this time based on trust as a substitute for something that has the equivalent economic value that is expected later on. The definition of credit that is more established for banking activities in Indonesia has been formulated in the Banking Act No.7 of 1992 which states that credit is the provision of money or bills that can be equated with it based on an agreement or loan agreement between the bank and other parties that require the borrowing party to carry out its obligations with a number of interests in return [14]. The analysis process and lending decisions are shown in Figure 1.

Credit analysis is one of the factors that can be used as a bank reference whether credit requests from customers can be approved or rejected, besides that the Bank needs to carry out in-depth analysis so that the bank avoids future credit problems. Some basic principles that need to be done before deciding on a prospective debtor application are known as the $5 \mathrm{C}$ principle.

The definition of Pairing Matrix which is a separate part of Analytical Hierarchy according to Thomas L. Saaty [15][16] is a flexible model that provides an opportunity for individuals or groups to build ideas and define problems by making their respective assumptions and get the desired solution.

\section{METHOD}

The method used in this study is Pairwise Comparisons and Scoring. Pairwise Comparisons, which are the basic part of the analytical hierarchy process, are methods that can divide a complex and unstructured condition into several elements by arranging in a hierarchical form. Every element in the hierarchy must know its relative weight. The goal is to determine the priority level of interests of interested parties in the issue of the criteria and overall hierarchical structure.

The first step in determining the priority criteria is to compile a paired comparison, which compares in the form of pairs of all criteria for each sub-hierarchy system. The comparison is then transformed in the form of a paired comparison matrix for numerical analysis. The hierarchical arrangement of criteria and sub-criteria carried out with priority weighting is shown in Figure 2.

Each criterion is arranged in the paired matrix shown in Table 1.

The priority setting steps can be explained as follows: 1. Add up each column in Table 1

$$
\begin{aligned}
K 1 & =\sum_{i=1}^{n} a[i, 1] \\
K 2 & =\sum_{i=1}^{n} a[i, 2] \\
K 3 & =\sum_{i=1}^{n} a[i, 3] \\
K 4 & =\sum_{i=1}^{n} a[i, 4] \\
K 5 & =\sum_{i=1}^{n} a[i, 5]
\end{aligned}
$$

where:

$i=$ line

$j=$ column

$n=$ criteria $(5)$

$K 1=$ number of columns character

$K 2=$ number of columns capacity

$K 3=$ number of columns capital

$K 4=$ number of columns collateral

K5=number of columns condition economy

2. Determining the value of the criteria column element with the formula for each cell in Table 1 divided by each number of columns.

$H k 1=(X 11 \ldots . X 15) / K 1$

$H k 2=(X 21 \ldots . X 25) / K 2$

$H k 3=(X 31 \ldots . X 35) / K 3$

$H k 4=(X 41 \ldots . . X 45) / K 4$

$H k 5=(X 51 \ldots . X 55) / K 5$

where:

$X 1 n=$ every cell column character

$X 2 n=$ every cell column capacity

$X 3 n=$ every cell column capital

$X 4 n=$ every cell column collateral

$X 5 n=$ every cell column condition economy

$H k 1=$ the result of each cell column character with the character column number.

$H k 2=$ the result of each cell column capacity with the capacity column number.

$H \mathrm{k} 3=$ the result of each cell column capital with the capital column number.

$\mathrm{Hk} 4=$ the result of each cell column collateral with the collateral column number.

$\mathrm{Hk} 5=$ the result of each cell column condition economy with the condition economy column number.

3. Determine the priority criteria for each row in Table 1 with the formula for the number of rows divided by many criteria.

$$
\begin{array}{ll}
B 1=\sum_{j=1}^{n} a[1, j] & P 1=B 1 / 5 \\
B 2=\sum_{j=1}^{n} a[2, j] & P 2=B 2 / 5 \\
B 3=\sum_{j=1}^{n} a[3, j] & P 3=B 3 / 5 \\
B 4=\sum_{j=1}^{n} a[4, j] & P 4=B 4 / 5 \\
B 5=\sum_{j=1}^{n} a[5, j] & P 5=B 5 / 5
\end{array}
$$




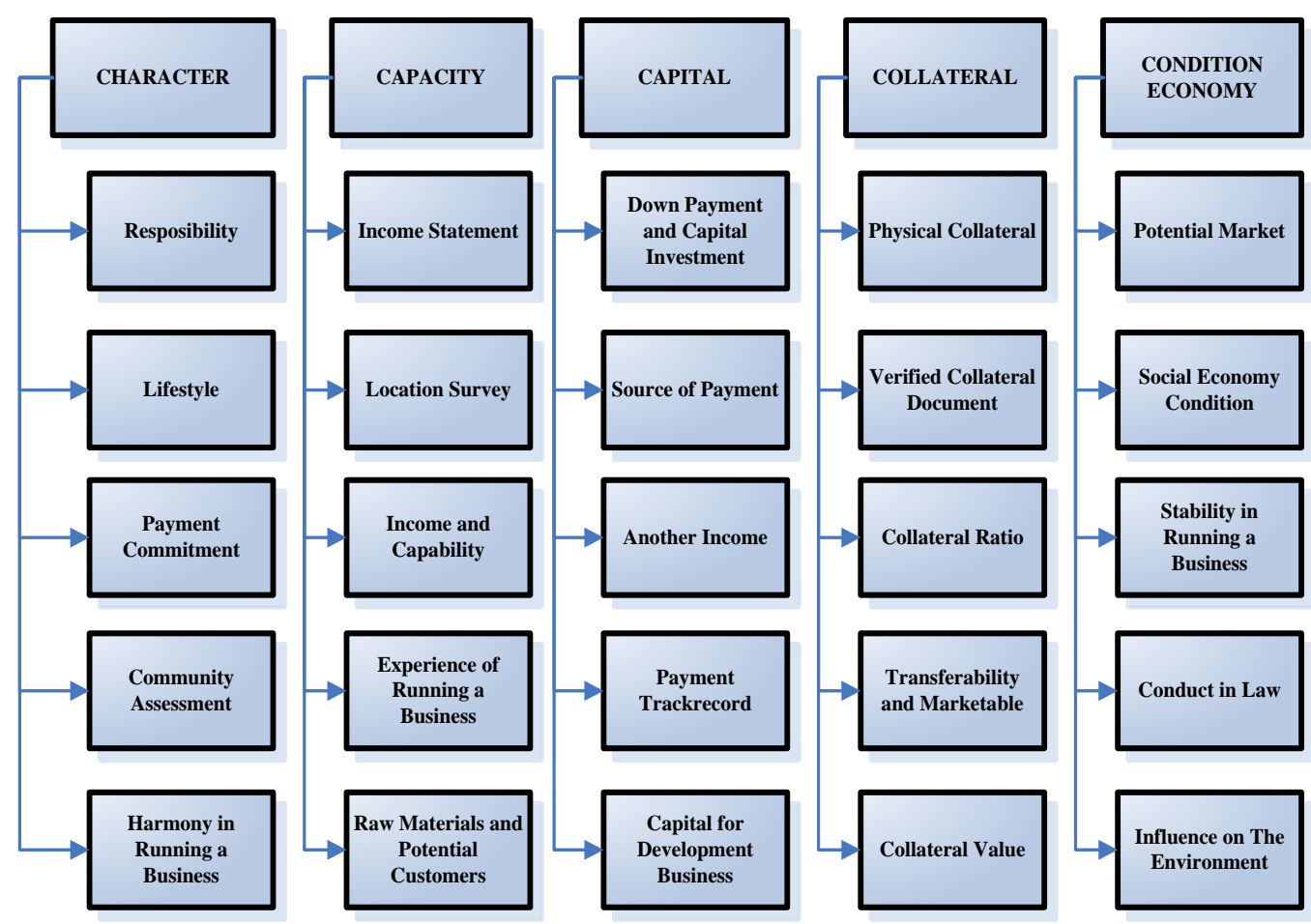

Figure 2. Hierarchy of Main Criteria and Sub Criteria.

where:

$n=$ criteria $(5)$

$B 1=$ number of lines character

$B 2=$ number of lines capacity

$B 3=$ number of lines capital

$B 4=$ number of lines collateral

B5 = number of lines condition Economy

$P 1=$ Priority character

$P 2=$ Priority capacity

$P 3=$ Priority capital

$P 4=$ Priority collateral

P5 = Priority condition Economy

4. See the consistency of data by calculating $\lambda$ max, $C I$ and $C R$

$\lambda 1=B p 1 / P 1$

$\lambda 2=B p 2 / P 2$

$\lambda 3=B p 3 / P 3$

$\lambda 4=B p 4 / P 4$

$\lambda 5=B p 5 / P 5$

where:

$n=$ criteria (5)

$\lambda 1=$ character

$\lambda 2=$ capacity

$\lambda 3=$ capital

$\lambda 4=$ collateral

$\lambda 5=$ condition economy

$$
\begin{aligned}
& C I=\frac{\lambda \max -n}{n-1} \\
& C R=\frac{C I}{R I}
\end{aligned}
$$

where:

CI $=$ Consistency Index

$C R=$ Consistency Ratio

$\lambda \max =$ eigenvalue maximum

$n \quad=$ criteria

After obtaining priority, the main criteria in determining prospective debtors then is to determine the priority of the sub-criteria of each of the main criteria using equations (1-22). Various other forms of scale have been proposed with different preference strength intervals, such as Power Scale [17], Geometric Scale [18], and Logarithmic Scale [19]. The examples presented from our approach use a scale of $1-9$, but any limited numerical scale can be used in this approach.

If there are inconsistencies in the results of the calculation, trade-off modeling can be carried out between modification assessments and a reduction in inconsistencies for a single decision maker [20]. This approach is to combine preferences for multi-objective optimization and focus on the underlying conflict. In addition, this approach also facilitates the transparency of the trade-offs involved when reaching consensus. Furthermore, this approach incorporates a reduction in inconsistencies during the aggregation process that seeks to reduce adverse effects on decision outcomes [21]. Pairwise Comparisons (PC) consistency is the extent to which the assessment is coherent. When there is inconsistency in the PC, each weight vector originating from it will only be an estimate of actual preference. As a result, different PCs will get different weight vectors. Besides, the higher the number of inconsistencies, the more weight vectors are derived to represent estimates of preference. PCs that are very inconsistent produce significant errors [22][23]

The scoring method is a method commonly referred to as a value scale, requiring a comparison norm so that it can be interpreted quantitatively. Basically, the interpretation of the value scale is always normative, meaning that the meaning of the value is referred to in the relative position of the value in a group that has been restricted beforehand. To measure the value of the selected main sub-criteria, a value level is needed. The levels of values used in this study are shown in Table 2.

After obtaining the value of each main sub-criteria selected, then it is to calculate the total value obtained by the following equation:

$$
S i=\sum G i j . W j
$$




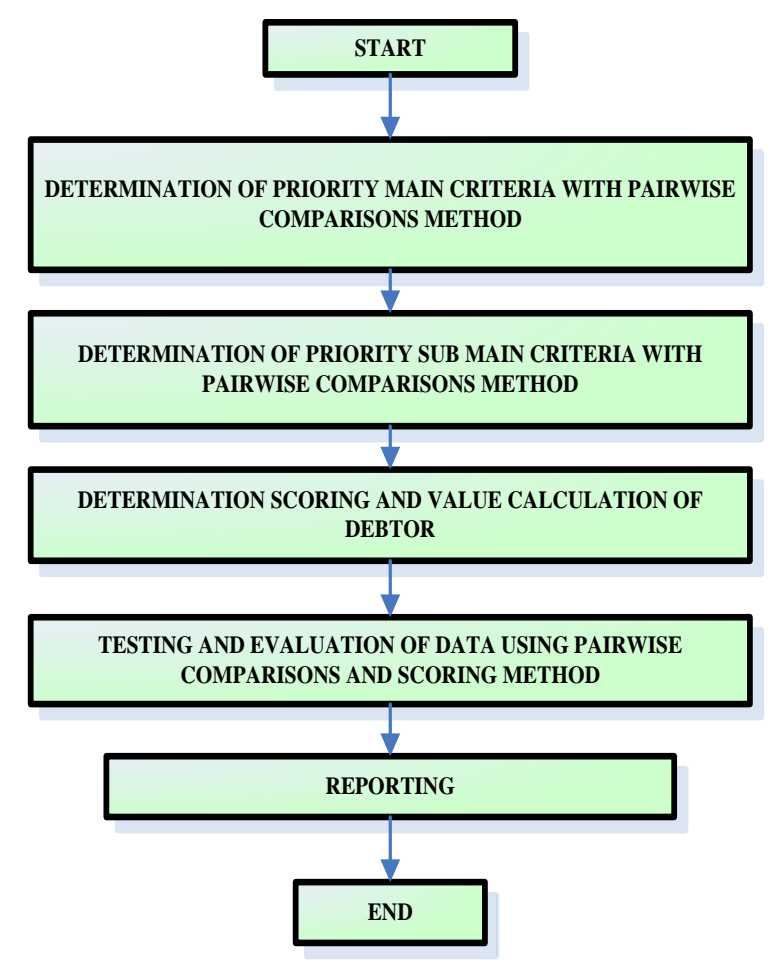

Figure 3. Research Metodology.

where:

$W j=A$ weight between 0 and 1 given in sub criteria $j$.

$S i=$ Total value for decision alternatives $i$.

Gij=The value category is between 0, 25, 50, 75, or 100 .

This study uses a case study, namely the mechanism of the Bank in determining the feasibility of debtors in receiving credit facilities. The implementation of the Pairwise Comparisons and Scoring method for analyzing this credit decision is based on the case study. The methodology used in this study is shown in Figure 3.

Based on Figure 3, the methodology used is divided into four main stages, namely:

A) Determination of Key Criteria Priorities (Stage 1)

The priority of the main criteria is obtained from the results of interviews, discussions, and questionnaires that were filled together by the Bank Management in charge of credit. Where the results of the questionnaire are arranged in a comparison matrix in pairs with the sequence of calculations according to the equation (122).

B) Determination of Priority of the Main Sub Criteria (Stage 2)

Determination of priority sub-criteria is obtained from the results of interviews, discussions, and questionnaires filled together by the Bank Management in charge of credit. Where the results of the questionnaire are arranged in a comparison matrix in pairs with the sequence of calculations according to the equation (122).

C) Scoring (Stage 3)

Determination of the level of scoring, namely 0, 25, 50, 75 , and 100 is obtained from the results of interviews and discussions with Bank Management in charge of credit. Where the results of the calculation of the value (scoring) of each debtor are obtained from the calculation of equation (23).

D) Data Testing and Evaluation (Stage 4)

Tests are conducted on 30 debtor proposals that submit credit facilities using calculations in equation (24).
TABLE 1.

PAIRWISE COMPARISONS MATRIX

\begin{tabular}{|c|c|c|c|c|c|}
\hline Criteria & Character & Capacity & Capital & Collateral & $\begin{array}{l}\text { Condition } \\
\text { Economy }\end{array}$ \\
\hline \multicolumn{6}{|l|}{ Character } \\
\hline \multicolumn{6}{|l|}{ Capacity } \\
\hline \multicolumn{6}{|l|}{ Capital } \\
\hline \multicolumn{6}{|l|}{ Collateral } \\
\hline \multicolumn{6}{|l|}{ Condition } \\
\hline \multicolumn{6}{|l|}{ Economy } \\
\hline Jumlah & & & & & \\
\hline
\end{tabular}

TABLE 2.

\begin{tabular}{cc}
\multicolumn{2}{c}{ ASSESSMENT CATEGORY } \\
\hline \hline No & Jenis Nilai \\
\hline 1 & 0 \\
2 & 25 \\
3 & 50 \\
4 & 75 \\
5 & 100 \\
\hline \hline
\end{tabular}

TABLE 3.

RESUlTS OF MAIN CRITERIA CALCULATION

\begin{tabular}{cc}
\multicolumn{2}{c}{ RESULTS OF MAIN CRITERIA CALCULATION } \\
\hline \hline Criteria & Priority Value \\
\hline Character & 0,1809 \\
Capacity & $\mathbf{0 , 3 0 8 6}$ \\
Capital & 0,2963 \\
Collateral & 0,1245 \\
Condition Economy & 0,0897 \\
\hline \hline
\end{tabular}

\section{RESULTS AND DISCUSSION}

Priorities for pairwise comparisons are needed to compare a pair of things or objects based on specific criteria. Weighting priority is a value that is used as consideration in assisting decision making. The priority weighting results of each criterion and sub-criteria used in the analysis of lending decision making are shown in Table 3-Table 8.

From the priority results obtained in each sub-criteria, the next step is to determine the value (scoring) for the sub-criteria, which has the highest priority weight, namely:

a. The responsibility which is described by the old company or business of the customer operating.

b. Income and Capability which is described with the results of notes or BI Checking reports of customers.

c. Source of Payment, which is illustrated by the growth in profits generated from the customer's business.

d. Physical Collateral which is described by the duration of collateral in the form of fixed assets owned by the customer.

e. Stability in Running a Business which is illustrated by the number of employees employed by customers.

The formulation of the Total Value (Scoring) of each debtor is the sum of multiplication between the Priority Value and the Weight Weight of Sub Criteria A, B, C, D or $\mathrm{E}$ as shown in the following equation:

$$
\sum(P 1 x A)+(P 2 x D)+(P 3 x E)+(P 4 x B)+(P 5 x C)
$$

where:

$P 1=$ Character with a criteria priority value of 0,1809

$P 2=$ Capacity with a criteria priority value of 0,3086

$P 3=$ Capital with a criteria priority value of 0,2963

$P 4=$ Collateral with a criteria priority value of 0,1245

$P 5=$ Condition with a criteria priority value of 0,0897

$A=$ The length of time the company or business is operating. 
TABLE 4.

RESUltS OF SUB CRITERIA CALCULATION (CHARACTER)

\begin{tabular}{clc}
\hline \hline No & \multicolumn{1}{c}{ Sub Criteria Character } & Priority Value \\
\hline 1 & Responsibility & 0,39 \\
2 & Lifestyle & 0,23 \\
3 & Payment Commitment & 0,16 \\
4 & Community Assessment & 0,12 \\
5 & Harmony in Running a Business & 0,10 \\
\hline \hline
\end{tabular}

TABLE 5.

RESUlTS OF SUb CRITERIA CALCULATION (CAPACITY)

\begin{tabular}{clc}
\hline \hline No & \multicolumn{1}{c}{ Sub Criteria Capacity } & Priority Value \\
\hline 1 & Income Statement & 0,06 \\
2 & Location Survey & 0,15 \\
3 & Income and Capability & $\mathbf{0 , 4 2}$ \\
4 & Experience of Running a Business & 0,21 \\
5 & Raw Materials and Potential Customers & 0,15 \\
\hline \hline
\end{tabular}

TABLE 6.

Results of Sub CRiteria CALCUlation (CAPITAL)

\begin{tabular}{clc}
\hline \hline No & \multicolumn{1}{c}{ CapitalSub Kriteria Capital } & Priority Value \\
\hline 1 & Down Payment and Capital Investment & 0,07 \\
2 & Source of Payment & $\mathbf{0 , 4 0}$ \\
3 & Another Income & 0,19 \\
4 & Payment Track record & 0,23 \\
5 & Capital for Development Business & 0,11 \\
\hline
\end{tabular}

TABLE 7.

RESUlts OF Sub CRiteria CALCUlation (COLlateral)

\begin{tabular}{clc}
\hline \hline No & \multicolumn{1}{c}{ Sub Criteria Collateral } & Priority Value \\
\hline 1 & Physical Collateral & $\mathbf{0 , 3 7}$ \\
2 & Verified Collateral Document & 0,29 \\
3 & Collateral Ratio & 0,06 \\
4 & Transferability and marketable & 0,13 \\
5 & Collateral Value & 0,16 \\
\hline \hline
\end{tabular}

TABLE 8.

Results of Sub Criteria Calculation (Condition Economy)

\begin{tabular}{clc}
\hline \hline No & \multicolumn{1}{c}{ Sub Criteria Condition Economy } & Priority Value \\
\hline 1 & Potential Market & 0,14 \\
2 & Social Economy Conditions & 0,08 \\
3 & Stability in Running a Business & $\mathbf{0 , 3 8}$ \\
4 & Conduct in Law & 0,21 \\
5 & Influence on The Environment & 0,19 \\
\hline \hline
\end{tabular}

TABLE 9.

RESUlts of CALCULATION AND PROPOSAL STATUS

\begin{tabular}{ccccccccc}
\hline \multirow{2}{*}{ No } & \multirow{2}{*}{ Proposal } & \multicolumn{7}{c}{ Proposal Status } \\
& \cline { 2 - 6 } & $\mathbf{A}$ & $\mathbf{B}$ & $\mathbf{C}$ & $\mathbf{D}$ & $\mathbf{E}$ & Total & \\
\hline & Priority Value & $\mathbf{1 8 , 0 8 7 3}$ & $\mathbf{1 2 , 4 5 2 7}$ & $\mathbf{8 , 9 7 0 3}$ & $\mathbf{3 0 , 8 6 2 6}$ & $\mathbf{2 9 , 6 2 7 2}$ & Value & Status \\
\hline 1 & Debitur 2 & 50 & 75 & 50 & 75 & 50 & 6.083 & Accepted \\
2 & Debitur 3 & 50 & 75 & 50 & 75 & 50 & 6.083 & Accepted \\
3 & Debitur 4 & 50 & 75 & 50 & 75 & 50 & 6.083 & Accepted \\
4 & Debitur 5 & 50 & 75 & 50 & 75 & 50 & 6.083 & Accepted \\
5 & Debitur 6 & 50 & 75 & 50 & 75 & 50 & 6.083 & Accepted \\
6 & Debitur 15 & 50 & 75 & 50 & 75 & 50 & 6.083 & Accepted \\
7 & Debitur 16 & 50 & 75 & 50 & 75 & 50 & 6.083 & Accepted \\
8 & Debitur 17 & 50 & 75 & 25 & 75 & 50 & 5.859 & Accepted \\
9 & Debitur 18 & 50 & 75 & 25 & 75 & 50 & 5.859 & Accepted \\
10 & Debitur 19 & 50 & 75 & 25 & 75 & 50 & 5.859 & Accepted \\
11 & Debitur 20 & 50 & 75 & 25 & 75 & 50 & 5.859 & Accepted \\
12 & Debitur 21 & 50 & 75 & 25 & 75 & 50 & 5.859 & Accepted \\
13 & Debitur 22 & 50 & 75 & 25 & 75 & 50 & 5.859 & Accepted \\
14 & Debitur 23 & 50 & 50 & 25 & 75 & 50 & 5.547 & Accepted \\
15 & Debitur 24 & 50 & 50 & 25 & 75 & 50 & 5.547 & Accepted \\
16 & Debitur 25 & 50 & 50 & 25 & 75 & 50 & 5.547 & Accepted \\
17 & Debitur 26 & 50 & 50 & 25 & 75 & 50 & 5.547 & Accepted \\
18 & Debitur 7 & 50 & 75 & 50 & 75 & 25 & 5.342 & Not Accepted \\
19 & Debitur 8 & 50 & 75 & 50 & 75 & 25 & 5.342 & Not Accepted \\
20 & Debitur 9 & 50 & 75 & 50 & 75 & 25 & 5.342 & Not Accepted \\
21 & Debitur 10 & 50 & 75 & 50 & 75 & 25 & 5.342 & Not Accepted \\
22 & Debitur 11 & 50 & 75 & 50 & 75 & 25 & 5.342 & Not Accepted \\
23 & Debitur 12 & 50 & 75 & 50 & 75 & 25 & 5.342 & Not Accepted \\
24 & Debitur 13 & 50 & 75 & 50 & 75 & 25 & 5.342 & Not Accepted \\
25 & Debitur 14 & 50 & 75 & 50 & 75 & 25 & 5.342 & Not Accepted \\
26 & Debitur 27 & 50 & 50 & 25 & 75 & 25 & 4.807 & Not Accepted \\
27 & Debitur 28 & 50 & 50 & 25 & 75 & 25 & 4.807 & Not Accepted \\
28 & Debitur 29 & 50 & 50 & 25 & 75 & 25 & 4.807 & Not Accepted \\
29 & Debitur 30 & 50 & 50 & 25 & 75 & 25 & 4.807 & Not Accepted \\
30 & Debitur 1 & 25 & 50 & 50 & 75 & 25 & 4.579 & Not Accepted \\
\hline \hline
\end{tabular}

Source Data Table 1-Table 9: Data Processing Results from Various Sources

(Questionnaire Results, Interviews, Discussions and Debtor Documentation from the Bank)

$B=$ The duration of collateral in the form of fixed assets is owned by the customer.

$C=$ Number of employees employed by customers.

$D=$ Results of notes or SLIK BI Checking customer reports.

$E=$ The profit growth generated from the customer's business.

The formulation of the debtor is accepted or not accepted using the following assessment results indicators:

A) Status Accepted, with indicators:
- Value of sub-criteria $A \geq 25$.

- Value of sub-criteria $B \geq 25$.

- Value of sub-criteria $C \geq 25$.

- Value of sub-criteria $\mathrm{D} \geq 50$.

- Value of sub-criteria $\mathrm{E} \geq 50$.

-The total value of the sum of all sub criteria $\geq 5000$. All KPI indicators above must be fulfilled and if there is one KPI indicator that is not met, the Status changes to Not Accepted.

B) Status Not Accepted, with indicators:

- Value of sub-criteria $A<25$. 
- Value of sub-criteria $\mathrm{B}<25$.

- Value of sub-criteria $C<25$.

- Value of sub-criteria $\mathrm{D}<50$.

- Value of sub-criteria $\mathrm{E}<50$.

-The total value of the sum of all sub criteria $<5000$.

The results of the calculation analysis of 30 debtor proposals submitting facilities are shown in Table 9.

From the calculation results shown in Table 9, it can be concluded that the results of Pairwise Comparisons and Scoring analysis can help determine the decision whether the debtor is feasible or not eligible to get a credit facility.

\section{CONCLUSION}

The results of prioritizing using pairwise comparison methods have produced a sequence of priorities for each criterion and sub-criteria. The scoring method has given value to each debtor. The results are as follows:

1) Priority sorting results from the main criteria, namely;

1. Capacity (0.3086)

2. Capital $(0,2963)$

3. Character $(0,1809)$

4. Collateral (0.1245)

5. Condition Economy (0.0897)

2) The highest priority results from the main sub-criteria, namely;

a) Responsibility.

b) Income and Capability.

c) Source of Payment.

d) Physical Collateral

e) Stability in Running a Business.

3) After obtaining priority criteria, the calculation of the total value (scoring) is carried out for each debtor using equation (24) with the calculation results presented in Table 9.

From the results of pairwise comparisons and scoring of 30 proposals, conclusions can be drawn as follows:

1) Testing of 30 proposals indicates that the results of the decision analysis are able to determine whether the debtor is feasible or not worthy of receiving the facility. 2) The results of this study can be a tool for the Bank in determining the results of the analysis of the decision of the recipient of the credit facility, but the final decision on the provision of facilities remains in the hands of the Bank.

For the Bank, the results of this study can be made an integrated decision support system that can be applied to each Bank Office, so that the Bank has the same reference in determining lending decisions.

The results of this analysis focus on the basis of determining the criteria, sub-criteria, and value categories sourced from a bank, given the possibility that the condition of a bank may be different from other banks. For this reason, further research can use data sources from various banks, so that more complex results can be obtained and banks can use the results of the analysis in general.

\section{REFERENCES}

[1] H. Yusvendy, "Analisis Keputusan Pemberian Kredit Modal Kerja Terhadap Usaha Kecil Mennenga (Studi Kasus Pada Bank BRI KCP Malang)," J. Univ. Brawijaya, 2014.

[2] Suyanto, "Penerapan Metode AHP Pada Sistem Penunjang Keputusan Kelayakan Pemberian Kredit,” in Seminar Nasional Teknologi Informasi dan Multimedia, 2014.

[3] H. Rahmawati, “Analisis Keputusan Pemberian Kredit Dalam Langkah Meminimalisir Kredit Bermasalah (Studi Kasus Pada Kredit Umum PT. Bank Rakyat Indonesia, Tbk. Slawi, Jawa Tengah)," J. Adm. Bisnis, vol. 35, no. 1, 2016.

[4] D. P. Dimas, "Sistem Pendukung Keputusan Pemberian Kredit menggunakan ID3," J. Teknol. Informasi-Aiti, vol. 14, no. 1, pp. 13-30, 2017.

[5] Al Karomi, "Sistem Pendukung Keputusan Persetujuan Kredit Menggunakan Algoritma C4.5," IC-Tech, vol. XI, no. 1, 2016.

[6] Heryanto, "The Study of Bank Nagari Credit Template, Indonesia," J. Internet Bank. Commer., vol. 22, no. S7, 2017.

[7] H. Sutri, "Analisis Keputusan Pemberian Kredit Modal Kerja Terhadap Usaha Kecil Menengah (Studi Kasus Pada PD BPR Bank)," J. Penelit. Ekon. dan Akunt., vol. III, no. 2, 2018.

[8] Nuzula, "Penerapan Analytical Hierarchy Process (AHP) Dalam Pengambilan Keputusan Pembiayaan Produktif (Studi Kasus Pada Bank Jatim Syariah Cabang Darmo," J. Ekon. Syariah Teor. dan Terap., vol. 3, no. 4, pp. 311-324, 2016.

[9] J. P. Brans, B. Mareschal, and P. Vincke, "PROMETHEE: a new family of outranking methods in multicriteria analysis," Oper. Res., vol. 84, pp. 477-490, 1984.

[10] C.-L. Hwang and K. Yoon, Multiple Attribute Decision Making, vol. 186. Berlin, Heidelberg: Springer Berlin Heidelberg, 1981.

[11] S. Opricovic, "Multicriteria Optimization of Civil Engineering Systems," Belgrade, 1998.

[12] L. Saaty, "A scaling method for priorities in hierarchical structures," J. Math. Psychol, vol. 15, no. 3, pp. 234-281, 1977.

[13] L. Saaty, Group decision making and the AHP, in The Analytic Hierarchy Process, Applications and Studies. Berlin: Springer, 1989.

[14] Peraturan Pemerintah Republik Indonesia, "Undang-Undang Perbankan No. 7 Tahun 1992," 1992.

[15] L. Saaty, The Analytic Hierarchy Process, Planning, Priority Setting, Resource Allocation. New York: Mc Graw Hill, 1980.

[16] T. L. Saaty and L. G. Vargas, Decision Making with the Analytic Network Process, vol. 195. Boston, MA: Springer US, 2013.

[17] P. Harker and L. Vargas, "The theory of ratio scale estimation: Saaty's analytic hierarchy process," Manage. Sci., vol. 33, no. 11, pp. 1383-1403, 1987.

[18] A. Lootsma, "Conflict resolution via pairwise comparison of concessions," Eur. J. Oper. Res., vol. 40, no. 1, pp. 109-116, 1989.

[19] A. Ishizaka, D. Balkenborg, and T. Kaplan, "Influence of aggregation and measurement scale on ranking a compromise alternative in AHP," Oper. Res., vol. 62, pp. 1-11, 2010.

[20] E. Abel, L. Mikhailov, and J. Keane, "Reducing inconsistency in pairwise comparisons using multi-objective evolutionary computing," in IEEE International Conference on Systems, Man, and Cybernetics (SMC), 2013, pp. 80-85.

[21] E. Abel, L. Mikhailov, and J. Keane, "Group aggregation of pairwise comparisons using multi-objective optimization," in Information Sciences, Science Direct, 2015, pp. 257-275.

[22] W. Koczkodaj and S. Szarek, "On distance-based inconsistency reduction algorithms for pairwise comparisons," Log. J. IGPL, vol. 18, no. 6, pp. 859-869, 2010.

[23] M. Kwiesielewicz and E.V. Uden, "Inconsistent and contradictory judgments in pairwise comparison method in the AHP," Comput. Oper. Res, vol. 31, pp. 713-719, 2004. 